\title{
IMPLEMENTASI PROTOKOL KESEHATAN DAN FAKTOR YANG MEMPENGARUHINYA TERHADAP ADAPTASI KEBIASAAN BARU PANDEMI COVID-19 DI WILAYAH KAMPUNG SANITASI KOTA TANGERANG SELATAN
}

\author{
Implementation Of Health Protocol And Factors That Influence On New Habits Adaptation Of
} The Covid-19 Pandemic In The Sanitation Village Area, Tangerang Selatan City

\author{
Muhammad Adjie Ramadhan, Arif Sumantri
}

Program Studi Kesehatan Masyarakat Fakultas IImu Kesehatan UIN Syarif Hidayatullah Jakarta muhammadadjieramadhan@gmail.com, 089601030013

\begin{abstract}
Covid-19 cases continue to increase due to the lack of care and implementation of government policies related to Covid19. The purpose of this study was to determine the implementation of the health protocol and the factors that influenced it to adapt to the new habits of the COVID-19 pandemic in the Sanitation Village area, South Tangerang City. This study uses a quantitative descriptive method using a cross-sectional study design. The sampling technique was total sampling with a sample of 78 housewives in the Sanitation Village area. Data were collected using questionnaires and interviews. The analysis used is univariate and bivariate analysis. The results showed that 45 respondents (57.7\%) did not implement the implementation of the Covid-19 health protocol. Factors related to the implementation of the Covid-19 health protocol are public attitudes, health information, facilities and infrastructure, and family support. In addition, the dominant variable related to the implementation of the Covid-19 health protocol is facilities and infrastructure with an OR value of $5.662 \mathrm{CI}$ (2.118-15.133). So respondents whose Covid-19 prevention facilities and infrastructure are not available have a 5,662 times higher chance of not implementing health protocols when compared to respondents whose Covid-19 prevention facilities and infrastructure are available. Therefore, researchers suggest that the local government can help the community not only with facilities and infrastructure but also build community attitudes to comply with the Covid-19 health protocol in the Sanitation Village area.

Keyword: Covid-19, Health Protocol Implementation, Sanitation Village.
\end{abstract}

\section{ABSTRAK}

Kasus Covid-19 terus meningkat disebabkan oleh kurang pedulinya dan penerapan kebijakan pemerintah terkait Covid19. Tujuan penelitian ini untuk mengetahui implementasi protocol kesehatan dan factor yang mempengaruhinya terhadap adaptasi kebiasaan baru pandemic covid-19 di wilayah Kampung Sanitasi Kota Tangerang Selatan. Penelitian ini menggunaka metode deskriptif kuantitatif dengan menggunakan desain studi cross-sectional. Teknik pengambilan sampel berupa total sampling dengan jumlah sampel 78 ibu rumah tangga diwilayah Kampung Sanitasi. Data dikumpulkan dengan menggunakan kuesioner dan wawancara. Analisis yang digunakan adalah analisis univariat dan bivariat.Hasil penelitian menunjukan bahwa 45 responden $(57,7 \%)$ tidak melakukan penerapan implementasi protokol kesehatan Covid-19. Faktor yang berhubungan dengan implementasi protocol kesehatan Covid-19 adalah, sikap masyarakat, informasi kesehatan, sarana dan prasarana, dan dukungan keluarga. Selain itu variable yang dominan berhubungan dengan implementasi protocol kesehatan Covid-19 adalah sarana dan prasarana dengan nilai OR 5,662 Cl $(2,118-15,133)$. Jadi responden yang sarana dan prasarana pencegahan Covid19-Nya tidak tersedia berpeluang 5,662 kali lebih tinggi untuk tidak melaksanakan implementasi protokol kesehatan jika dibandingkan dengan responden yang sarana dan prasarana pencegahan Covid-19 nya tersedia. Oleh karena itu peneliti menyarankan untuk pemerintah setempat dapat membantu masyarakat bukan hanya sarana dan prasarana tetapi juga membangun sikap masyarakat untuk mematuhi protocol kesehatan Covid-19 diwilayah Kampung Sanitasi.

Kata Kunci: Covid-19, Implementasi Protokol Kesehatan, Kampung Sanitasi

\section{PENDAHULUAN}

Di Indonesia bertepatan pada tanggal 14 Maret 2020 terdapat sebanyak 96 kasus yang terkonfirmasi Covid-19 dengan jumlah kematian 6 orang dan menjadi negara ke 65 yang positif konfirmasi Covid-19. Penambahan jumlah kasus Covid-19 berlangsung cukup cepat dan sudah terjadi penyebaran ke luar wilayah Wuhan dan negara lain. 11 Desember 2020 Indonesia memiliki kasus covid-19 positif sebanyak 605.243 kasus diantaranya sembuh 496.886 kasus dan kasus meninggal 18.511, ini merupakan kasus tertinggi nomor 1 di Asia Tenggara. Provinsi Banten pada 15 Desember 2020 memiliki jumlah kasus 15.276 dengan kasus sembuh 3600 kasus dan kasus meninggal dunia sebanyak 381 kasus. Tangerang selatan menduduki peringkat pertama kasus tertinggi Covid-19 yaitu 3.225 kasus.

Peradangan Covid- 19 bisa memunculkan indikasi ringan, sedang ataupun berat. Indikasi klinis utama yang timbul ialah demam (temperatur $38^{\circ} \mathrm{C}$ ), batuk serta kesusahan bernapas. Tidak hanya itu bisa diiringi dengan sesak memberat, fatigue, mialgia, indikasi gastrointestinal semacam diare serta indikasi saluran nafas lain. Separuh dari penderita mengalami sesak dalam satu minggu. Pada kasus berat perburukan secara cepat dan progresif, semacam 
Jurnal Sulolipu : Media Komunikasi Sivitas Akademika dan Masyarakat

Vol. 21 No.2 2021

e-issn : 2622-6960, p-issn : 0854-624X

ARDS, syok septik, asidosis metabolik yang susah dikoreksi serta perdarahan ataupun disfungsi sistem koagulasi dalam sebagian hari. Pada sebagian penderita, indikasi yang timbul ringan, apalagi tidak diiringi dengan demam. Mayoritas penderita mempunyai prognosis baik, dengan sebagian kecil dalam keadaan kritis hingga meninggal dunia.

Setelah mewabahnya kasus Covid-19 dikeluarkanlah beberapa regulasi yang berupaya mengurangi persebaran kasus Covid-19 di Indonesia. Dalam memutus rantai Covid-19, juga dilakukan karantina bagi yang terinfeksi Covid dan penerapan berbagai pencegahan Covid bagi yang tidak terinfeksi. Protokol kesehatan merupakan pedoman utama masyarakat dalam penerapan pencegaha Covid-19. Salah satunya yaitu PERMENKES nomor 328 Tahun 2020 tentang Protokol Kesehatan bagi masyarakat di tempat umum dalam rangka pencegahan dan pengendalian Covid-19, dalam pencegahan dan pengendaliannya terdapat berbagai perilaku dan sikap yang harus dilakukan dan ditaati setiap masyarakat agar mata rantai Covid19 terputus. Diantaranya, mencuci tangan pakai sabun/sanitizer, menggunakan masker, menjaga jarak, menjaga daya tahan tubuh dan membatasi mobilitas (5M). Walikota Tangerang Selatan juga mengeluarkan surat keputusan terkait Gugus Percepatan Penanganan Covid-19, dalam Keputusan Walikota Tangerang Selatan Nomor 443/Kep.101-Huk tahun 2020. Pada 24 November 2020, Wali Kota Tangerang Selatan, Airin Rachmi Diany, mengeklaim tingkat kepatuhan warganya menjalankan protokol kesehatan (prokes) mencapai $79 \%$. Masyarakat Tangsel dinilai telah paham penggunaan alat pelindung diri (APD) seperti masker dan face shield pada saat beraktivitas di luar ruangan. Dengan harapan tingkat kesadaran protokol kesehatan bisa mnecapai angka ideal di angka $90 \%$.

Kampung Sanitasi ini merupakan kampung binaan Himpunan Ahli Kesehatan Lingkungan Indonesia (HAKLI). Beberapa penerapan yang diterapkan oleh HAKLI dalam pencegahan dan pemutusan mata rantai kasus Covid-19 yaitu memberikan pelatihan kepada warga terkait cara membuat sabun antiseptik mencegah dan meningkatkan perilaku cuci tangan pakai sabun untuk mencegah infeksi virus corona ini. Selain itu HAKLI juga ingin mewujudkan $\begin{array}{ccc}\text { terciptanya satu kampung yang } & \begin{array}{c}\text { kamangan } \\ \text { berwawasan }\end{array} \text { lingkungan } & \text { untuk }\end{array}$ meningkatkan derajat kesehatan

Kampung Sanitasi nantinya akan menjadi kampung percontohan untuk perbaikan kesehatan lingkungan di Indonesia khususnya pada wilayah penelitian yaitu Kota Tangerang Selatan. Kampung Sanitasi adalah sebuah kampung yang terletak di RW 03 RT 03 Kelurahan Rawa Mekar Jaya, Tangerang Selatan. Daerah ini nantinya akan dijadikan kampung yang sehat berdasarkan paradigma kesehatan lingkungan. Kampung ini merupakan daerah pemukiman yang diresmikan dalam upaya penyelenggaraan kesehatan lingkungan pada tahun 2019. Dalam mewujudkan misi Kota Tangerang Selatan untuk mencipatakan kota layak huni yang berwawasan lingkungan, adanya kampung sanitasi ini diharapkan dapat menjadi pintu masuk permukiman berwawasan lingkungan.

Berdasarkan wawancara terhadap tokoh masyarakat, dan warga setempat. Masih banyak masyarakat sekitar kampung sanitasi yang tidak mematuhi protokol kesehatan, baik pencegahan individu maupun pencegahan massal (seluruh masyarakat). Masyarakat belum menyadari akan pentingnya program-program pencegahan Covid-19 yang telah dirancang dan ditetapkan oleh pemerintah untuk memutus mata rantai Covid-19 yaitu mencuci tangan pakai sabun/sanitizer, menggunakan masker, menjaga jarak, menjaga daya tahan tubuh dan membatasi mobilitas (5 M).

Oleh karena itu perlu adanya tindak lanjut dan pendalaman menganai penerapan implementasi protokol kesehatan pada adaptasi kebiasaan baru pandemi Covid-19 diwilayah Kampung Sanitasi, Kelurahan Rawa Mekar Jaya, Tangerang Selatan tahun 2020.

\section{METODE}

\section{Desain, tempat dan waktu}

Jenis penelitian ini adalah deskriptif kuantitatif dengan menggunakan desain studi cross sectional. Dengan penelitian kuantitatif, Penelitian ini dilakukan pada bulan November 2020 sampai dengan Januari 2021 terhitung sejak penyusunan proposal hingga laporan hasil. Penelitian ini dilakukan di Kampung Sanitasi yang terletak di RT03/RW03, Kelurahan Rawa Mekar 
Jurnal Sulolipu : Media Komunikasi Sivitas Akademika dan Masyarakat

Vol. 21 No.2 2021

e-issn : 2622-6960, p-issn : 0854-624X

Jaya Kecamatan Rawabuntu Kota Tangerang Selatan.

\section{Jumlah dan Cara Pengambilan Subjek}

Jumlah sampel dalam penelitian ini adalah sebanyak 78 sampel yaitu ibu rumah tangga. Pengambilan sampel atau mengambil dengan jumlah sampel yang sama dengan populasi, dapat disebut dengan teknik total sampling.

\section{Jenis dan Cara Pengumpulan Data}

Pengumpulan data dalam penelitian ini berupa pengumpulan data primer. Data primer diperoleh melalui wawancara terstruktur menggunakan kuesioner berisi pertanyaan seputar penerapan covid-19 dan factor-faktornya. Penyebaran kuesioner dilakukan secara langsung dengan kata lain peneliti turun kelapangan untuk melihat hasil lebih jelas dari penerapan implementasi protokol kesehatan Covid-19 dan faktorfaktor yang berhubungan dengan protokol kesehatan Covid-19.

\section{Pengolahan dan Analisis Data}

Pengolahan data pada penelitian ini dilakukan dengan programmer terdapat beberapa tahapan diantaranya editing (Penyuntungan data dan proses pengumpulan data), coding (pengklasifikasian data), entry/processing (proses input data kedalam programmer), dan cleaning (proses pembersihan/koreksi data). Data dianalisis dengan uji chi-square.

\section{HASIL}

Kampung Sanitasi terletak di Kelurahan Rawa Mekar Jaya, Kota Tangerang Selatan. Secara administratif lingkungan kampung sanitasi ini berada di wilayah RT 003 RW 003 Kelurahan Rawa Mekar Jaya Tangerang Selatan yang masuk ke dalam wilayah kerja Puskesmas Rawabuntu, Jumlah kepala keluarga di RT 003 RW 003 berjumlah $78 \mathrm{KK}$ dan jumlah penduduknya (Kelurahan Rawa Mekar Jaya, 2019). Pembangunan kesehatan di kampung sanitasi dalam tahap perencanaan.

Berdasarkan hasil survey lingkungan kampung sanitasi, 65 dari 78 responden (89\%) tidak tahu apa itu kampung sanitasi, 4 dari 73 responden $(5,5 \%)$ responden berpendapat bahwa kampung sanitasi merupakan yang bersih, 4 dari 73 responden $(5,5 \%)$ berpendapat bahwa kampung sanitasi adalah suatu bentuk lingkungan permukiman yang dapat dijadikan contoh bagi kampung lain atau wilayah permukiman lain. Hasil wawancara dengan ketua RT 003, penerapan protokol kesehatan belum berjalan dengan baik, beberapa masyarakat sudah mengetahui protocol kesehatan yang telah di wajibkan, tetapi masyarakat masih belum peduli akan hal tersebut. Terlihat dari banyaknya masyarakat yang tidak memakai masker, menjaga jarak, dan membatasi mobilitas.

Berdasarkan hasil penelitian, dapat diketahui bahwa terdapat 37 orang atau sebanyak $87,9 \%$ responden yang tidak melaksanakan implementasi protokol kesehatan dan memiliki sikap negatif terhadap Covid-19. Sedangkan, 8 orang lainnya atau sebanyak $22,2 \%$ responden tidak melaksanakan protokol kesehatan dan memiliki sikap positif terhadap Covid-19. Selain itu terdapat 5 orang atau sebanyak Hasil uji statistika menunjukkan nilai Pvalue 0,000 artinya pada nilai a 0,05 ada hubungan signifikan antara implementasi protokol kesehatan dengan sikap masyarakat terhadap Covid-19. Selain itu diperoleh nilai OR 2,588 (1,001-6,693).

Berdasarkan hasil penelitian, dapat diketahui bahwa terdapat 34 orang atau sebanyak $73,9 \%$ responden yang tidak melaksanakan implementasi protokol kesehatan dan tidak mendapatkan informasi kesehatan terkait pencegahan Covid-19. Sedangkan, 12 orang lainnya atau sebanyak $34,4 \%$ responden tidak melaksanakan protokol kesehatan dan mendapatkan informasi kesehatan terkait pencegahan Covid-19. Hasil uji statistika menunjukkan nilai Pvalue 0,001 artinya pada nilai $\alpha 0,05$ ada hubungan signifikan antara implementasi protokol kesehatan dengan informasi kesehatan. Selain itu diperoleh nilai OR 5,409 (2,025-14,448).

Berdasarkan hasil penelitian, dapat diketahui bahwa terdapat 32 orang atau sebanyak $76,2 \%$ responden yang tidak melaksanakan implementasi protokol kesehatan dan tidak tersedianya sarana dan prasarana pencegahan Covid-19. Sedangkan, 13 orang lainnya atau sebanyak $36,1 \%$ responden tidak melaksanakan protokol kesehatan dan tersedianya sarana dan prasarana pencegahan Covid-19. Hasil uji statistika menunjukkan nilai Pvalue 0,001 artinya pada nilai a 0,05 ada hubungan signifikan antara implementasi protokol kesehatan dengan sarana dan prasarana 
Jurnal Sulolipu : Media Komunikasi Sivitas Akademika dan Masyarakat

Vol. 21 No.2 2021

e-issn : 2622-6960, p-issn : 0854-624X

pencegahan Covid-19. Selain itu diperoleh nilai OR 5,662 (2,118-15,133)

Berdasarkan hasil penelitian, dapat diketahui bahwa terdapat 37 orang atau sebanyak $69,8 \%$ responden yang tidak melaksanakan implementasi protokol kesehatan dan tidak mendapat dukungan dari keluarga. Sedangkan, 8 orang lainnya atau sebanyak $32 \%$ responden tidak melaksanakan protokol kesehatan dan mendapat dukungan dari keluarga. Selain itu terdapat 16 orang atau sebanyak $30,2 \%$ yang melaksanakan implementasi protokol kesehatan dan tidak mendapat dukungan dari keluarga sedangkan 17 orang lainnya atau sebanyak $68 \%$ melaksanakan implementasi protokol kesehatan dan mendapat dukungan dari keluarga. Hasil uji statistika menunjukkan nilai Pvalue 0,004 artinya pada nilai a 0,05 ada hubungan signifikan antara implementasi protokol kesehatan dengan dukungan keluarga. Selain itu diperoleh nilai OR 4,914 (1,76413,692).

Berdasarkan hasil penelitian, dapat diketahui bahwa terdapat 23 orang atau sebanyak $67,6 \%$ responden yang tidak melaksanakan implementasi protokol kesehatan dan tidak mendapat dukungan dari tenaga kesehatan. Sedangkan, 22 orang lainnya atau sebanyak $50 \%$ responden tidak melaksanakan protokol kesehatan dan mendapat dukungan dari tenaga kesehatan. Hasil uji statistika menunjukkan nilai Pvalue 0,182 artinya pada nilai a 0,05 tidak ada hubungan signifikan antara implementasi protokol kesehatan dengan dukungan tenaga kesehatan.

Berdasarkan hasil penelitian, dapat diketahui bahwa terdapat 33 orang atau sebanyak $66 \%$ responden yang tidak melaksanakan implementasi protokol kesehatan dan tidak mendapat dukungan dari tokoh masyarakat. Sedangkan, 12 orang lainnya atau sebanyak 42,9\% responden tidak melaksanakan protokol kesehatan dan mendapat dukungan dari tokoh masyarakat. Hasil uji statistika menunjukkan nilai Pvalue 0,081 artinya pada nilai a 0,05 tidak ada hubungan signifikan antara implementasi protokol kesehatan dengan dukungan tokoh masyarakat.

\section{PEMBAHASAN}

Dalam penelitian ini variabel implementasi protokol kesehatan Covid-19 dibagi menjadi dua kategori, yaitu melakukan penerapan implementasi protokol kesehatan Covid-19 dan tidak melakukan penerapan implementasi protokol kesehatan Covid-19. Berdasarkan hasil analisis dalam penelitian ini, lebih banyak masyarakat yang tidak melakukan penerapan implementasi protokol kesehatan Covid-19, dibandingkan dengan masyarakat yang melakukan penerapan implementasi protokol kesehatan Covid-19.

Hasil penelitian ini selaras dengan penelitian yang dilakukan (Dea, 2020) menunjukkan bahwa masyarakat belum menerapkan protokol kesehatan dengan baik. Bahkan sebagian besar masyarakat tidak melakukan protokol untuk menjaga kebersihan tangan. Berbeda dengan penelitian yang dilakukan (Afrianti, 2021) yaitu diketahui bahwa $89,6 \%$ masyarakat memiliki kepatuhan yang tinggi terhadap protokol kesehatan Covid 19.

Hasil analisis deskriptif menunjukkan masyarakat yang tidak menerapkan implementasi protocol Kesehatan lebih banyak yang memiliki sikap negatif dibandingkan yang memiliki sikap positif. Hasil uji statistik menunjukkan adanya hubungan yang signifikan antara implementasi protokol kesehatan Covid-19 dengan sikap masyarakat di wilayah kampung sanitasi kelurahan rawa mekar jaya. Sebagaimana yang dikemukakan Green dan Keuter dalam (Notoatmodjo, 2012), bahwa sikap merupakan faktor predisposisi yang dapat memengaruhi perilaku seseorang.

Berdasarkan penjelasan di atas diketahui bahwa jumlah responden bersikap negatif lebih banyak dibandingkan dengan responden bersikap positif.

Dalam riset (Winarti, 2020) menampilkan terdapatnya ikatan antara perilaku dengan kepatuhan terhadap kebijakan PSBB dengan $p$ value sebesar 0 , 000 . Selaras dengan riset (Saroni $A, 2018$ ) dan penelitian (Azmi FZ, 2016) terpaut kepatuhan terhadap peraturan( KTR) yang melaporkan kalau terdapat ikatan antara perilaku dengan kepatuhan terhadap peraturan yang ada.

Adanya hubungan antara implementasi protokol kesehatan Covid-19 dengan sikap masyarakat karena tidak berpengaruhnya Covid-19 dengan kondisi kesehatan pada masyarakat yang disebabkan kurang percayanya terhadap Covid-19 dan minimnya pengetahuan tentang pentingnya 
Jurnal Sulolipu : Media Komunikasi Sivitas Akademika dan Masyarakat

Vol. 21 No.2 2021

e-issn : 2622-6960, p-issn : 0854-624X

mengatasi pencegahan Covid-19 yang menyebabkan minimnya respons sikap positif dari masyarakat di Wilayah Kampung Sanitasi Kelurahan Rawa Mekar Jaya.

Masyarakat yang berpendapat tidak mendapatkan informasi Covid-19 lebih banyak dibandingkan dengan masyarakat yang mendapatkan informasi terkait Covid19. Jika dilihat dari hasil crosstab kategori responden pada kelompok tidak mendapatkan informasi dengan implementasi tidak melaksanakan mengenai protokol kesehatan Covid-19 lebih banyak dibandingkan responden yang mendapatkan informasi dengan implementasi tidak melaksanakan mengenai protokol kesehatan Covid-19. Hasil uji statistik juga menunjukkan adanya hubungan yang signifikan antara implementasi protokol kesehatan Covid-19 dengan informasi masyarakat di wilayah kampung sanitasi kelurahan rawa mekar jaya.

Berdasarkan hasil penelitian menunjukkan bahwa masyarakat di wilayah kampung sanitasi kelurahan rawa mekar jaya tidak seluruhnya mendapatkan informasi terkait Covid-19 baik melalui siaran berita online dan tv, radio, media sosial, atau bimbingan konseling tentang pencegahan Covid-19 dari puskesmas setempat. Sehingga minimnya informasi yang di dapat mempengaruhi implementasi protokol kesehatan masyarakat upaya pencegahan Covid-19.

Berdasarkan hasil penelitian, menunjukan bahwa masih banyak masyarakat yang belum memiliki sarana dan prasarana yang memadai dalam upaya pencegahan penyebaran Covid-19, sebagian responden belum memiliki alat pelindung diri (masker), bahan untuk desinfeksi, dan antiseptik. Sebaiknya masyarakat memiliki sarana dan prasarana Covid-19 seperti masker, desinfektan, handsanitizer untuk mencegah ditularkan dan menularkannya Covid-19 kepada sesama.

Penelitian yang dilakukan oleh (Kusumastuti, 2020) Responden dengan kategori kepatuhan tinggi juga lebih banyak dilakukan oleh responden yang memiliki tersedianya sarana prasarana yang baik. Penelitian yang sama dilakukan oleh (Nismawati, 2020) responden yang sarana dan prasarananya tersedia menerapkan protokol kesehatan lebih banyak dibandingkan dengan responden yang tidak tersedia sarana dan prasarana dengan menerapkan protokol kesehatan dengan pvalue $(0,000)$ yang artinya terdapat pengaruh signifikan antara keterediaan sarana dan prasarana dengan penerapan protokol keehatan.

Adanya hubungan antara implementasi protokol kesehatan Covid-19 dengan sarana dan prasarana Covid-19 karena tidak adanya fasilitas yang menunjang masyarakat untuk menerapkan anjuran pemerintah dengan baik dan maksimal disebabkan keterbatasan kondisi dalam masyarakat, dan kurangnya referensi tentang Covid-19 menjadi salah satu faktor mengenai pentingnya sarana dan prasarana untuk menunjang pencegahan Covid-19.

Sebagian besar responden sudah didukung dengan tenaga kesehatan seperti kegiatan, mengajak dan memberikan informasi mengenai Covid-19 dari petugas kesehatan puskesmas/kader, namun tidak sedikit yang belum mendapatkan dukungan dari petugas kesehatan puskesmas/kader. Beberapa responden mengaku mendapatkan dukungan dari tenaga Kesehatan. Namun, mereka tidak melakukan protocol kesehatan sesuai apa yang telah dianjurkan oleh tenaga kesehatan.

Tidak adanya hubungan yang signifikan antara implementasi protokol kesehatan Covid-19 dengan dukungan tenaga kesehataan dikarenakan masyarakat merasa tidak berpresepsi bahwa faktor dukungan dari tenaga kesehatan itu penting untuk penerapan protokol kesehatan Covid19 , yang menyebabkan minimnya informasi dan peran aktif dari tenaga kesehatan, selain itu masyarakat juga merasa kurangnya edukasi dan dorongan petugas kesehatan yang dilakukan kepada masyarakat diwilayah Kampung Sanitasi, kondisi yang tidak memungkinkan untuk turun langsung kewilayah menjadi salah satu faktor petugas kesehatan dalam memberikan dorongan kepada masyarakat, terlebih jika kurangnya komunikasi antara tokoh masyarakat dengan warga terkait Covid-19.

Berdasarkan hasil analisis deskriptif terkait dukungan tokoh masyarakat, lebih banyak masyarakat yang tidak dapat dukungan dari tokoh masyakarat dibandingkan masyarakat yang mendapatkan dukungan dari tokoh masyarakat. Proporsi kategori responden 
Jurnal Sulolipu : Media Komunikasi Sivitas Akademika dan Masyarakat

Vol. 21 No.2 2021

e-issn : 2622-6960, p-issn : 0854-624X

pada kelompok tidak mendapat dukungan dari tokoh masyarakat dan tidak melaksanakan implementasi protokol kesehatan Covid-19 lebih banyak dibandingkan dengan kelompok responden yang mendapat dukungan dari tokoh masyarakat dan tidak melaksanakan implementasi mengenai protokol kesehatan Covid-19. Hasil uji statistik menunjukkan tidak ada hubungan yang signifikan antara implementasi protokol kesehatan Covid-19 dengan dukungan tokoh masyarakat di wilayah kampung sanitasi kelurahan rawa mekar jaya

Berdasarkan hasil penelitian, didapatkan sudah banyak responden yang mendapatkan dukungan dari keluarga terkait informasi Covid-19, penerapan protokol kesehatan, serta arahan penerapan social distancing, tetapi masih ada beberapa responden yang masih belum mendapatkan dukungan yang cukup dari keluarga mengenai implementasi protokol kesehatan Covid-19.

\section{KESIMPULAN}

Berdasarkan pembahasan dari penelitian yang telah dilakukan, dapat ditarik kesimpulan, bahwa terdapat hubungan signifikan antara sikap masyarakat, saranaprasarana, informasi kesehatan dan dukungan keluarga terhadap implementasi protokol kesehatan covid-19 diwilayah Kampung Sanitasi Kota Tangerang Selatan.

\section{SARAN}

Dalam upaya penyelenggaraan kesehatan lingkungan di kampung sanitasi disarankan kepada masyarakat kampung sanitasi untuk meningkatkan partisipasi dan kondisi sanitasi dasar dalam pengelolaan limbah sebagai potensi daya dukung lingkungan. Kepada Puskesmas Rawabuntu disarankan untuk melakukan edukasi dan pembinaan secara menyeluruh terkait dampak pencemaran lingkungan akibat tidak mengelola limbah, serta memanfaatkan potensi/peluang daya dukung lingkungan dan kemampuan partisipasi masyarakat untuk dikembangkan.

\section{DAFTAR PUSTAKA}

Adityo,dkk. 2020. Coronavirus Disease tinjauan literatur terkini. Jurnal penyakit dalam, Vol.7 No.1 Afrianti, N. R. (2021). Faktor-faktor yang mempengaruhi kepatuhan masyarakat. Jurnal IImiah Permas: Jurnal IImiah STIKES Kendal Volume 11 No 1, 119.

Anisa, P. (2020). Tingkat Pengetahuan dan Perilaku Masyarakat Kabupaten Wonosobo tentang Covid-19. Jurnal Ilmiah Kesehatan hal 33-42.

Ashidiqie, M. L. (2020). Peran Keluarga Dalam Mencegah Corona Virus Disease. SALAM; Jurnal Sosial \& Budaya Syar-I Vol. 7 No. 10 DOI: 10.15408/sjsbs.v7i8.15411, 911-922.

Azmi FZ, I. T. (2016). Hubungan Penerapan Kawasan Tanpa Rokok (KTR) dengan Perilaku Merokok Mahasiswa Kesehatan Masyarakat di Kota Semarang. . Jurnal Kesehat Masy ;4(3):, 995-1004.

Dea, F. (2020). Analisis Dampak Pandemi Corona Virus Terhadap Tingkat Kesadaran . Wellness and healthy magazine Volume 2, Issue 2, 237-249.

Direktorat Promosi Kesehatan Kementerian Kesehatan RI, 2020. Kumpulan Media CTPS. Diakses melalui : http://promkes.kemkes.go.id/kumpulan-media-ctps Pada tanggal 24 Juli 2020

Dirjend Pencegahan dan Pengendalian Penyakit Kemenkes RI. 2020. Pedoman Pencegahan dan Pengendalian COVID-19.

Dr. dr. Erlina Burhan Msc. Sp.P(K). 2020. Coronavirus disease 2019 (COVID-19). Departemen Pulmonologi dan IImu Kedokteran Respirasi FKUI - RSUP Persahabatan Satgas. Waspada dan Siaga COVID-19 PB IDI.

Dr. Irwan, S.KM, M.Kes. Buku Etika dan Perilaku Kesehatan. 2017. CV Absolute Media : Yogyakarta

Fatimah, N. (2019). Pengertian Sarana dan Prasarana, Fungsi Hingga Contohnya

Galia Wardha Alvita, S. H. (2021). Pemberdayaan dukungan keluarga dalam meningkatkan pemahaman pencegahan covid-19 di masyarakat kabupaten demak. Jurnal Pengabdian Kesehatan STIKES Cendekia Utama Kudus Vol. 4, No. 1, .

Gugus Tugas Percepatan Penanganan COVID-19, 2020. Situasi Virus Corona. Diakses melalui : https://www.Covid19.go.id/situasi-virus-corona/ Pada tanggal 2 Agustus 2020 
Jurnal Sulolipu : Media Komunikasi Sivitas Akademika dan Masyarakat

Vol. 21 No.2 2021

e-issn : 2622-6960, p-issn : 0854-624X

Indriyanti, D. (2020). Implementasi protokol kesehatan pada petugas puskesmas di masa pandemi: studi kasus puskesmas cileungsi kabupaten bogor. MONAS: Jurnal Inovasi Aparatur Vol. 2 No. 2 , 235-246.

Kementerian Kesehatan RI, 2020. Pedoman Pencegahan dan Pengendalian Coronavirus Disease (COVID-19). 1st ed. Jakarta: Kementerian Kesehatan.

Keputusan Walikota Tangerang Selatan Nomor 443/Kep.101-Huk tahun 2020 tentang Percepatan Gugus Penanganan Covid-19

Kundari, N. F. (2020). Hubungan Dukungan Sosial dan Keterpaparan Media Sosial terhadap Perilaku Pencegahan COVID-19 pada Komunitas Wilayah Jabodetabek Tahun 2020. Media Penelitian dan Pengembangan Kesehatan, Vol. 30 No. 4, $281-294$.

Kusumastuti, W. A. (2020). Determinan kepatuhan masyarakat kota depok terhadap kebijakan pembatasan sosial berskala besar dalam pencegahan covid-19. Jurnal Kebijakan Kesehatan Indonesia : JKKI, Vol. 09, No. 03.

Menteri Kesehatan RI, 2020. Surat Edaran Nomor Hk.02.01/Menkes/335/2020 Tentang Protokol Pencegahan Penularan Coronavirus Disease (Covid-19) di Tempat Kerja Sektor Jasa dan Perdagangan (Area Publik) dalam Mendukung Keberlangsungan Usaha, Jakarta: Kementerian Kesehatan.

Menteri Kesehatan, 2020. Keputusan Menteri Kesehatan Republik Indonesia Nomor Hk.01.07/Menkes/382/2020 Tentang Protokol Kesehatan Bagi Masyarakat di Tempat Dan Fasilitas Umum Dalam Rangka Pencegahan dan Pengendalian Coronavirus Disease 2019 (Covid-19), Jakarta: Kementerian Kesehatan.

Menteri kesehatan, 2020. Keputusan Menteri Kesehatan RI Nomor Hk.01.07/Menkes/328/2020 Tentang Panduan Pencegahan dan Pengendalian Coronavirus Disease 2019 (Covid-19) di Tempat Kerja Perkantoran dan Industri dalam Mendukung Keberlangsungan Usaha pada Situasi Pandemi, Jakarta: Kementerian Kesehatan RI.

Menteri Kesehatan, 2020. Peraturan Menteri Kesehatan No. 9 Tahun 2019 Tentang Pedoman Pembatasan Sosial Berskala Besar (PSBB) Dalam Rangka Percepatan Penanganan Coronavirus Disease 2019, Jakarta: Kementerian Kesehatan.

Nismawati. (2020). Faktor Yang Berhubungan Dengan Penerapan Protokol Kesehatan Pada Pelaku Usaha Mikro Selama masa Pandemi Covid -19. UNM Environmental Journals, Vol.3 No.3, 116 - 124.

Notoatmodjo, S. (2010). Pengantar Pendidikan Kesehatan dan IImu Perilaku. Yogyakarta: Andi Offset.

Notoatmodjo, S., 2012. IImu Perilaku Kesehatan. Jakarta: Rineka Cipt

Notoatmodjo, S., 2012. Promosi Kesehatan dan Perilaku Kesehatan. 1. Jakarta: Rineka Cipta

Nova Nurwinda Sari, D. Y. (2020). Jurnal Peduli Masyarakat, Volume 2 No 4, 173-180.

Peraturan Pemerintah nomor 66 tahun 2014 tentang Kesehatan Lingkungan.

Permenkes Nomor 9 Tahun 2020 Tentang Pedoman Pembatasan Sosial Berskala Besar Dalam Rangka Percepatan Penanganan Corona Virus Disease (Covid-19)

Presiden Republik Indonesia, 2020. Keputusan Presiden RI No 11 Tahun 2020 tentang penetapan kedaruratan Kesehatan Masyarakat Corona Virus Disease 2019 (COVID-19), DKI Jakarta: Kementerian Kesekertariatan Negara.

Pusat Penelitian Badan Keahlian DPR RI. 2020. Penyebaran Covid dan Respon International. VOL XII, NO.5.

Riksa, D. (2020). Analisis Perilaku Masyarakat Indonesia dalam Menghadapi Pandemi Virus Corona (Covid-19) dan Kiat Menjaga Kesejahteraan Jiwa. SALAM Jurnal Sosial dan Budaya Syar $i, 6$.

Risnawaty, Gracia. 2016. Faktor Determinan Perilaku Cuci Tangan Pakai Sabun (CTPS) Pada Masyarakat Di Tanah Kalikedinding. Jurnal Promkes, Vol.4 No.1

Sarlia S. Analisis Model Komunikasi Karyawan Kantor BPJS Kesehatan dalam Penyampaian Informasi Pada Masyarakat Kota Kendari. J Imu Komun UHO. 2017;2(2):1-21.

Saroni A, S. A. (2018). Faktor-faktor yang Berhubungan Dengan Kepatuhan Masyarakat Desa Winong Kecamatan Pati Kabupaten Pati Dalam Pelaksanaan Peraturan Daerah Nomor 10 Tahun 2014 Tentang Kawasan Tanpa Rokok. Jurnal Kesehat Masy ;6(4):; 1-9.

Sugiyono. (2017). Metode Penelitian Kuantitatif, Kualitatif, dan R\&D. Bandung : Alfabeta, CV.

Tentama, F. (2018). Penerapan Perilaku Hidup Bersih Dan Sehat (Phbs) Demi Kesejahteraan Masyarakat Kecamatan Tuntang Kabupaten Semarang Jawa Tengah. Jurnal 
Jurnal Sulolipu : Media Komunikasi Sivitas Akademika dan Masyarakat

Vol. 21 No.2 2021

e-issn : 2622-6960, p-issn : 0854-624X

Pemberdayaan: Publikasi Hasil Pengabdian Kepada Masyarakat. https://doi.org/10.12928/jp.v1i1.309

Webster RK, B. S. (2020). How to Improve Adherence with Quarantine: Rapid Review of The Evidence. Public Health. , 163.

Widya, Utami. 2010. Faktor Faktor yang Berhubungan Dengan Cuci Tangan Pakai Sabun Pada Masyarakat di Desa Cikoneng. FKM UI

Winarti, A. d. (2020). Determinan Kepatuhan Masyarakat Kota Depok Terhadap Kebijakan Pembatasan Sosial Berskala Besar dalam Pencegahan Covid-19. Jurnal Kebijakan Kesehatan Indonesia: JKKI Volume 09 No. 03, 117-124.

World Health Organization Sout-East Asia, 2020. COVID-19 Situation in the WHO South-East Asia Region. Diakses melalui : https://experience.arcgis.com/experience/56d2642cb379485ebf78371e744 b8c6a. pada tanggal 2 Agustus 2020

Wulan, W. A. (2020). Determinan Kepatuhan Masyarakat Kota Depok Terhadap Kebijakan Pembatasan Sosial Berskala Besar dalam Pencegahan Covid-19. Jurnal Kebijakan Kesehatan Indonesia: JKKI Volume 09 No. 03 , 117-124. 
Jurnal Sulolipu : Media Komunikasi Sivitas Akademika dan Masyarakat

Vol. 21 No.2 2021

e-issn : 2622-6960, p-issn : 0854-624X

\section{Tabel 1}

Hubungan Implementasi Protokol Kesehatan Covid-19 dengan Faktor Yang Mempengaruhinya di wilayah Kampung Sanitasi Rawa Mekar Jaya

\begin{tabular}{|c|c|c|c|c|c|}
\hline \multirow[t]{2}{*}{ No } & \multirow{2}{*}{$\begin{array}{c}\text { Faktor - Faktor } \\
\text { Penerapan Protokol } \\
\text { Kesehatan Covid-19 }\end{array}$} & \multicolumn{2}{|c|}{$\begin{array}{c}\text { Implementasi Protokol Kesehatan } \\
\text { Covid-19 }\end{array}$} & \multirow[t]{2}{*}{$\begin{array}{c}\text { OR } \\
(95 \% \mathrm{Cl})\end{array}$} & \multirow[t]{2}{*}{ P-value } \\
\hline & & Melaksanakan & $\begin{array}{c}\text { Tidak } \\
\text { Melaksanakan }\end{array}$ & & \\
\hline 1 & $\begin{array}{l}\text { Sikap Negatif } \\
\text { Terhadap } \\
\text { Penerapan Protokol } \\
\text { Covid-19 }\end{array}$ & 37 orang $(87,9 \%)$ & 5 orang $(11,9 \%)$ & $\begin{array}{l}2,588(1,001- \\
6,693)\end{array}$ & 0,000 \\
\hline 2 & $\begin{array}{l}\text { Tidak menerima } \\
\text { informasi terkait } \\
\text { Protokol Covid-19 }\end{array}$ & 34 orang $(73,9 \%)$ & 12 orang $(26,1 \%)$ & $\begin{array}{l}5,409 \\
(2,025-14,448)\end{array}$ & 0,001 \\
\hline 3 & $\begin{array}{l}\text { Tidak menyediakan } \\
\text { sarana dan } \\
\text { prasarana Protokol } \\
\text { Covid-19 }\end{array}$ & 32 orang $(76,2 \%)$ & 10 orang $(23,8 \%)$ & $\begin{array}{l}5,662 \\
(2,118-15,133)\end{array}$ & 0,001 \\
\hline 4 & $\begin{array}{l}\text { Tidak mendapat } \\
\text { dukungan tenaga } \\
\text { kesehatan }\end{array}$ & 23 orang $(67,6 \%)$ & 11 orang $(32,4 \%)$ & $\begin{array}{l}2,091 \\
(0,825-5,301)\end{array}$ & 0,182 \\
\hline 5 & $\begin{array}{l}\text { Tidak mendapat } \\
\text { dukungan tokoh } \\
\text { masyarakat } t\end{array}$ & 33 orang $(66 \%)$ & 17 orang (34\%) & $\begin{array}{l}2,588 \\
(1,001-6,693)\end{array}$ & 0,081 \\
\hline 6 & $\begin{array}{l}\text { Tidak mendapat } \\
\text { dukungan keluarga }\end{array}$ & 37 orang $(69,8 \%)$ & 16 orang $(30,2 \%)$ & $\begin{array}{l}4,914 \\
(1,764-13,692)\end{array}$ & 0,004 \\
\hline
\end{tabular}

